Phinisi Integration Review
Vol. 3, No.2, Agustus 2020 Hal 165-172
Website: $\underline{\text { http://ojs.unm.ac.id/pir }}$
p-ISSN: 2614-2325 dan e-ISSN: $2614-2317$
DOI: https://doi.org/10.26858/pir.v3i2.14426

\title{
Pernikahan Tolotang di Kelurahan Amparita Kecamatan Tellu Limpoe Kabupaten Sidenreng Rappang
}

\author{
Wihdaniah $^{1}$, Andi Agustang ${ }^{2}$, Arlin Adam ${ }^{3}$ \\ ${ }^{12}$ Pendidikan Sosiologi, Universitas Negeri Makassar, Indonesia \\ Email: ${ }^{1}$ wihdaniahnani4@gmail.com
}

\begin{abstract}
Abstrak. Penelitian ini bertujuan untuk (i) Mendeskripsikan Proses Pernikahan Towani Tolotang Di Kelurahan Amparita Kecamatan Tellu Limpoe Kabupaten Sidenreng Rappang (ii) Mendeskripsikan mengapa proses perkawinan Towani Tolotang tetap bertahan di tengah arus modernisasi kehidupan. (iii) Mendeskripsika nilai-nilai sosial dalam perkawinan Towani Tolotang di Kelurahan Amparita Kecamatan Tellu Limpoe Kabupaten Sidenreng Rappang? Jenis penelitian yang digunakan deskriptif kualitatif yang bertujuan untuk menggambarkan pernikahan Tolotang Di Kelurahan Amparita Kecamatan Tellu Limpoe Kabupaten Sidenreng Rappang. Adapun teknik pengumpulan data yaitu dengan melakukan observasi, wawancara, dan dokumentasi. Teknik pengabsahan data yaitu triangulasi sumber yaitu untuk mengkaji kredibilitas data yang dilakukan dengan cara mengecek data yang telah di peroleh melalui beberapa sumber. Dari hasil penelitian ditemukan bahwa (i) Proses Pernikahan Towani Tolotang Di Kelurahan Amparita Kecamatan Tellu Limpoe Kabupaten Sidenreng Rappang yaitu berawal dari tahapan sebelum nikah (pra nikah), tahapan nikah/resepsi dan tahapan setelah nikah (pasca nikah) (ii) proses perkawinan Towani Tolotang tetap bertahan di tengah arus modernisasi kehidupan karena adanya keyakinan yang kuat yang bersumber dari nenek moyang dan adanya keinginan mempertahankan tradisi. (iii) nilai-nilai sosial dalam pernikahan Towani Tolotang di Kelurahan Amparita Kecamatan Tellu Limpoe Kabupaten Sidenreng Rappang yaitu nilai gotong royong, nilai tolong menolong, nilai kekeluargaan, nilai kepedulian, dan nilai pengormatan.
\end{abstract}

Kata Kunci: Pernikahan, Tolotang, Konsistensi

\begin{abstract}
This study aims to (i) Describe the Tolotang Towani Marriage Process in Amparita Village Tellu Limpoe District Sidenreng Rappang Regency (ii) Describe why the Towani Tolotang marriage process continues to survive in the midst of the modernization of life. (iii) Describe the social values in the Towani Tolotang marriage in Amparita Village, Tellu Limpoe District, Sidenreng Rappang Regency? This type of research is descriptive qualitative which aims to describe the Tolotang marriage in Amparita Village, Tellu Limpoe District, Sidenreng Rappang Regency. The data collection techniques are by conducting observations, interviews, and documentation. The data validation technique is source triangulation, which is to examine the credibility of the data by checking the data that has been obtained through several sources. From the results of the study it was found that (i) Tolotang Towani Marriage Process in Amparita Village Tellu Limpoe District Sidenreng Rappang Regency, which starts from the stage before marriage (pre-marriage), the stage of marriage / reception and the stage after
\end{abstract}


marriage (post-marriage) (ii) the process of Towani marriage Tolotang still survives in the midst of the modernization of life because of the strong conviction that comes from ancestors and the desire to maintain tradition. (iii) social values in the Towani Tolotang marriage in Amparita Village, Tellu Limpoe Subdistrict, Sidenreng Rappang Regency, namely mutual cooperation values, help values, family values, values of caring, and values of respect.

Keywords: Marriage, Tolotang, Consistenc.

Ini adalah artikel dengan akses terbuka dibawah licenci CC BY-NC-4.0

(https://creativecommons.org/licenses/by-nc/4.0/).

\section{PENDAHULUAN}

Kepulauan Indonesia terdiri atas 13.000 pulau besar maupun kecil, dan dihuni oleh 316 suku bangsa yang menggunakan lebih kurang 250 bahasa daerah, sehingga setiap suku memiliki kebudayaannya sendiri. Seperti yang kita ketahui, bahwa keragaman budaya di Indonesia sangat luas sekali mulai dari bahasa, upacara adat, norma-norma, pakaian adat, dan seni. Upacara adat pun ada berbagai macam, salah satu contonya adalah prosesi pernikahan. Prosesi pernikahan yang ada di Indonesia memiliki banyak ragam serta variasi yang berdasarkan atas suku bangsa, agama maupun kelas sosial.

Dalam pernikahan adat memiliki rentetan prosesi yang cukup panjang mulai dari persiapan pernikahan, resepsi serta acara setelah pernikahan yang dilakukan secara adat sehingga dibutuhkan kesiapan mental serta materi untuk melaksanakannya. Jadi tak heran jika pernikahan adat sedikit demi sedikit mulai ditinggalkan terlebih lagi pada zaman sekarang ini masyarakat telah mengikuti arus modernisasi yang mana dapat membuat sesuatu yang dapat dikatakan rumit menjadi lebih mudah. Arus modernisasi inilah yang mampu mempengaruhi pola pikir dalam masyarakat. Namun terdapat salah satu komunitas adat yang masih tetap mempertahankan tradisi/budaya lokalnya yang merupakan warisan leluhurnya, komunitas adat tersebut ialah komunitas adat Tolotang. Tolotang sendiri merupakan salah satu komunitas adat yang masih eksis ditengahtengah arus modernisasi. (Bahri, 2012) Tolotang ketika diartikan secara Harfiah, terdiri atas dua kata yang terungkap dalam bahasa Bugis, yaitu "to=tau", yang berarti orang dan kata "lotang", yang berarti selatan, yaitu nama salah satu mata angin dalam bahasa Bugis. Jadi Tolotang sebenarnya berarti orang-orang yang bertempat tinggal pada bagian selatan. Namun Tolotang yang dimaksud dalam penelitian ini sebenarnya hanyalah merupakan salah satu komunitas adat yang mampu membertahankan tradisi leluhurnya walaupun hidup dalam posisi keminoritasan.

Dalam masyarakat Tolotang sendiri terdapat dua kelompok, yaitu masyarakat Benteng (orang Tolotang yang sudah pindah Agama Tolotang). Dan masyarakat Towani Tolotang (komunitas yang masih menganut agama Tolotang). Namun di dalam penelitian ini, peneliti memfokuskan pada komunitas adat Towani Tolotang.

Bagi masyarakat Tolotang sebelum melakukan peresmian pernikahan di wajibkan bagi keluarga kedua calon pengantin untuk melaksanakan yang namanya mappenre inanre. Apabila mereka tidak memenuhi kewajibannya maka acara yang dilaksanakan tidak dianggap oleh uwa'nya. Bahkan dua atau tiga kali tidak melaksanakan kewajiban tersebut tanpa alasan yang dipaparkan di depan uwa'nya maka akan dikeluarkan dari kepercayaan tersebut. Menurut keyakinan mereka bahwa mengantar sesajiansesajian menandakan kesetiaan kepada uwa'nya dan menandakan bahwa mereka masih menganut adat istiadat Tolotang.

Dalam proses Pernikahan komunitas Towani Tolotang sendiri terbilang unik dan memiliki prosesi yang panjang mulai dari pranikah, nikah dan pasca nikah. Walaupun Tolotang mengidentifikasikan dirinya sebagai suku bugis namun dalam hal perkawinan memiliki perbedaan dengan pernikahanpernikahan suku bugis lainnya. pada umumnya, ketika masyarakat lain mengadakan pesta pernikahan menyewa gedung ataupun menyewa 
tenda namun pada komunitas Towani Tolotang tetap melakukan pernikahan di dalam rumah, ciri khas prosesi pernikahan komunitas adat Tolotang adalah semua tamu yang hadir duduk bersila dilantai papan rumah panggung, khusus pemangku adat atau tamu kehormatan akan duduk diatas tikar daun lontar yang telah disiapkan oleh yang punya hajat. Adapun makna duduk bersila tersebut adalah kebersamaan dan kesetaraan pada masyarakat Tolotang sendiri masih dijunjung tinggi. Rumah komunitas Towani Tolotang sendiri adalah rumah panggung yang tiangnya berbentuk segi delapan dengan rumah yang bisa di bongkar pasang pada dinding rumah. Apabila komunitas Towani Tolotang melakukan prosesi pernikahan maka bagian depan rumah (lego-lego) akan di buka dan ditambah untuk menerima tamu dan biasa disebut dengan sarapo, sarapo adalah simbol tanda adanya pernikahan.

Keunikan yang lain juga terdapat pada pakaian yang mereka kenakan dalam acara-acara penting seperti halnya pernikahan, mereka tetap menggunakan kebaya dan kain sarung yang merupakan pakaian tradisional wanita Indonesia, mereka tidak terpengaruh dengan penampilan wanita Sidenrreng Rappang yang tergolong glamour walaupun mereka mampu untuk melakukannya. Dan untuk kesehariannya mereka menggunakan kain sarung bagi wanita dan kopiah hitam dilengkapi kain sarung bagi pria.

Komunitas Towani Tolotang mempunyai pandangan yang khusus terhadap pernikahan yang syarat dengan nilai-nilai. Tercermin dari keteguhan masyarakat Tolotang dalam menjaga tradisi pernikahan yang bersumber dari nenek moyang yang mereka yakini. Walaupun banyak daerah yang telah meninggalkan kebiasaan-kebiasaanya yang merupakan tradisi secara turun temurun namun pada masyarakat Tolotang, mereka masih konsisten dalam menjalankan tradisi dalam hal pernikahan. Hal inilah yang membuat peneliti tertarik untuk mengangkat judul "Pernikahan Tolotang di Kelurahan Amparita Kecamatan Tellu Limpoe Kabupaten Sidenrreng Rappang”

\section{METODE}

Metode merupakan suatu prosedur atau cara untuk mengetahui sesuatu dengan langkahlangkah yang sistematis (Agustang. A, 2015) Metode Penelitian adalah cara ilmiah untuk mendapatkan data dengan tujuan dan kegunaan

tertentu (Agustang. A, 2011b) Adapun metode penelitian yang digunakan yakni deskriptif kualitatif yaitu suatu metode penelitian yang dilakukan dengan membuat gambaran atau deksripsi tentang suatu keadaan secara objektif. Penelitian kualitatif bertujuan untuk memahami realitas sosial, yaitu melihat subjek penelitian dari apa adanya, bukan dari apa yang seharusnya. Pemahaman tentang realitas akan mempengaruhi cara pemerolehan ilmu pengetahuan yang benar (Agustang. A, 2011a). Metode kualitatif digunakan dalam menggambarkan tentang bagaimana pernikahan Towani Tolotang di Kelurahan Amparita Kecamatan Tellu Limpoe Kabupaten Sidenreng Rappang.

Penelitian yang baik akan menghasilkan paradigma yang baru dalam pengembangan ilmu pengetahuan, dimana hasil pemikiran paradigma selalu tidak mencukupi dan terbuka untuk perubahan selanjutnya. Dengan kata lain hasil pemikiran melalui perubahan paradigma akan selalu bersifat relative, hal ini bergantung pada data dan fakta yang diperoleh dari dunia nyata yang kemudian dianalisis menurut kaidahkaidah ilmiah (Agustang. A, 2011a). Dalam menentukan informan penelitian, dilakukan menggunakan teknik purposive sampling. Dimana purposive sampling adalah teknik penentuan informan dengan mempertimbangkan kriteria tertentu yang telah ditetapkan oleh peneliti sebelumnya. Teknik pengumpulan data yang digunakan adalah observasi, wawancara dan dokumentasi. Teknik analisis data kualitatif tipe deskriptif melalui tiga tahap yaitu reduksi data, penyajian data, dan penarikan kesimpulan. Teknik pengabsahan data dalam penelitian ini adalah triangulasi. Triangulasi yang digunakan dalam penelitian ini adalah triangulasi sumber.

\section{HASIL DAN PEMBAHASAN}

Untuk memperjelas hasil penelitian yang telah dipaparkan diatas, maka penulis akan membahas mengenai data- data yang diperoleh dari lokasi penelitian. Untuk lebih jelasnya dipaparkan sebagai berikut:

1. Proses Pernikahan Towani Tolotang Di
Kelurahan Amparita Kecamatan Tellu
Limpoe Kabupaten Sidenreng Rappang
Pada pembahasan ini akan dibahas
mengenai proses pernikahan towani tolotang Di
Kelurahan Amparita Kecamatan Tellu Limpoe
Kabupaten Sidenreng Rappang. Berdasarkan
penelitian yang dilakukan, ditemukan ada 17


rangkaian pernikahan Towani Tolotang yang di kelompokkan menjadi 3 bagian yakni (1). Tahapan sebelum pernikahan (pra-nikah) yang terdiri atas Mabbaja Laleng, artinya melakukan penyelidikan untuk mengetahui asal usul maupun latar belakang perempuan yang akan dilamar (b) Madduta/Lettu, yakni proses melamar pihak perempuan (c) Mappetu Ada, adalah proses perundingan kedua belah pihak keluarga mengenai hal-hal yang menyangkut pernikahan hingga sepakat (d) Mappaenre Paddopo Addeng adalah proses mengikat secara resmi calon pengantin perempuan dengan symbol menyerahkan sokko dan pallise kerumah perempuan (e) Massarapo adalah proses mendirikan bangunan tambahan sebagai tempat menerima tamu dan resepsi (f) Tangke adalah calon mempelai perempuan berdiam diri serta merawat dirumah sebelum hari pernikahan $(\mathrm{g})$ Mappenre Dui/ Pattere Pese adalah proses penyerahan uang belanja kepada pihak calon mempelai perempuan dan juga penyerahan berbagai jenis buah dan juga makanan yang memiliki rasa manis yang bermakna setelah pernikahan dilaksanakan maka keluarga mempelai nanti akan hidup bahagia dan selalu harmonis (h) Diyo Majeng, adalah proses memandikan calon mempelai laki-laki dengan bunga kelapa yang bermakna mensucikan calon pengantin (i) Mapacci, adalah proses untuk mensucikan calon mempelai laki-laki dengan memakai daun pacar (j) Lolang adalah pihak laki-laki mengantarkan barang berupa alat keperluan wanita ke rumah calon mempelai perempuan.

(2) Tahapan nikah/resepsi yaitu mappenre botting adalah proses mengantar pengantin laki-laki kerumah pengantin perempuan untuk melakukan peresmian pernikahan (b) Tudang Botting adalah acara resepsi setelah peresmian pernikahan dan pemberian doa restu dari para tamu undangan

(c) Mapparola adalah terjadi kunjungan balasan dari mempelai perempuan kerumah mempelai laki-laki.

(3) Tahapan setelah pernikahan (pasca nikah) yaitu (a) Mabbeni Siwenni adalah proses dimana mempelai perempuan akan menginap dirumah mempelai laki-laki selama 1 malam ataupun sebaliknya dimaksudkan untuk mengenalkan perempuan kepada keluarga lakilaki serta bertujuan mendekatkan serta salin mengenal diantara kedua mempelai, (b) Maccera Kawing adalah ritual memohon agar pernikahan senantiasa mendapat perlindungan dari Dewata
Sewwae yang didoakan langsung oleh Uwa, (c) Mappaleppang adalah proses memanggil kedua mempelai untuk singgah oleh kerabat terdekat dan adanya pemberian berupa barang yang bernilai sebagai bekal berumah tangga. Hal ini sesuai dengan teori AGIL dari Talcott Person (Ritzer, 2012: 410) yakni Pencapaian tujuan yang menyebutkan "suatu sistem harus mendefinisikan dan mencapai tujuan utamanya". Adanya tahapan mappaleppang ini dapat mempererat kekerabatan antar keluarga serta membantu kedua mempelai dalam menjalani kehidupan berumah tangga dari modal yang diberikan saat prosesi mappaleppang, sehingga walaupun tidak sedikit dana yang dikeluarkan saat melakukan hajatan namun terdapat pula keuntungan bagi kedua mempelai yakni pemberian barang yang bernilai, baik yang berupa tanah ataupun yang lainnya yang dapat dimanfaatkan kedua mempelai nantinya sehingga tradisi seperti ini kan menjadi daya dorong masyarakat untuk tetap melaksanakan tradisi pernikahan tersebut tanpa harus mengkhawatirkan kehidupan selanjutnya setelah acara selesai. (d) mabbolo adalah proses mengunjungi kuburan leluhur atau biasa disebut ziarah kubur, menurut keyakinan masyarakat setempat leluhur akan penyampaian laporan bahwa telah bersatunya kedua mempelai kepada dewata sewwae

Berdasarkan hasil observasi dan wawancara yang dilakukan bahwa dari tahapan atau proses dalam tradisi pernikahan Towani Tolotang merupakan pernikahan yang dapat dikatakan cukup panjang dan membutuhkan kesiapan mental, tenaga maupun materi. Berbeda dengan masyarakat modern yang kebanyakan menjadikan sebuah acara pernikahan yang tadinya merupakan prosesi yang panjang menjadi lebih simple, namun bagi komunitas adat Towani Tolotang masih tetap melaksanakan apa yang telah menjadi kebiasaan dari nenek moyangnya tersebut.

\section{Konsistensi Pernikahan Towani Tolotang Di Tengah Arus Modernisasi Kehidupan}

Berdasarkan hasil wawancara dan observasi yang dilakukan, komunitas adat Towani Tolotang mampu mempertahankan tradisi pernikahannya karena ada dua hal yang mempengaruhinya yakni (1) adanya keyakinan yang kuat yang bersumber dari nenek moyang, mereka percaya bahwa apa yang telah diwariskan oleh nenek moyang mereka adalah hal-hal yang akan membuat kehidupan mereka 
lebih terarah dengan adanya kepercayaan terhadap dewata sewwae. Hal tersebut menunjukkan adanya Latensi (pemeliharaan pola) dalam teori AGIL Talcott Person, (Ritzer, 2012) yang menyatakan bahwa " suatu sistem

harus menyediakan, memelihara, dan memperbarui baik motivasi para individu maupun pola-pola budaya yang menciptakan dan menopang motivasi itu". Kepercayaan yang bersumber dari nenek moyang baik berupa tradisi atau kebiasaan-kebiasaan yang dipercayai oleh Towani Tolotang yang merupakan pendorong maupun pengontrol bagi setiap sikap dan tingkah laku dalam masyarakat Towani Tolotang sehingga mereka percaya jika tradisi atau kebiasaan-kebiasaan tersebut masih dilaksanakan maka akan membuat kehidupan mereka lebih terarah. Dalam pembentukan keyakinan tersebut tidak serta merta seseorang dapat dengan mudah yakin terhadap suatu hal, maka terdapat 2 peran yang dilakukan dalam membentuk keyakinan dalam komunitas adat Towani Tolotang yaitu (a) peran orang tua, yakni dengan mengikutsertakan sang anak untuk ikut dalam pernikahan yang ia ikuti selain itu biasanya orang tua akan memberikan nama sang anak dengan nama nenek moyangnya (b) peran uwa/uwatta (pemangku adat) yakni, memberikan wejangan-wejangan, petunjuk-petunjuk tentang ajaran maupun tradisi tempo dulu. ketika seorang telah mencapai pencerahan tentang "jati diri" maka ia akan mendapatkan hakekat ketuhanan dan tujuan kehidupan. (Agustang, 2010). Dalam Teori struktural fungsional menjelaskan bagaimana berfungsinya suatu struktur, setiap struktur (mikro seperti persahabatan meso seperti organisasi dan makro seperti masyarakat dalam arti luas seperti masyarakat jawa) akan tetap ada sepanjang ia memiliki fungsi, (Damsar, 2015). Seperti yang telah dijelaskan diatas dalam masyarakat Tolotang ada 2 peran yang berjalan dengan baik, yakni orang tua dan pemangku adat yang merupakan struktur yang telah berfungsi dengan baik sehingga pernikahan Tolotang bertahan hingga sekarang.

Bertahannya tradisi tersebut merupakan fakta sosial yang terjadi dalam masyarakat, fakta sosial sendiri merupakan cara bertindak, berfikir dan berperasaan yang berada diluar individu dan mempunyai kekuatan memaksa yang mengendalikan, (Ritzer, 2010) Disini dapat dilihat bahwa bagaimana orang tua secara tidak langsung memaksakan anaknya untuk ikut dalam setiap acara pernikahan yang ia hadiri kemudian pemangku adat menanamkan keyakinan, ajaran-ajaran serta tradisinya yang harus diterima dan diaplikasikan dalam kehidupan sehari-hari. Penanaman tradisi pernikahan yang dilakukan sejak dini lambat laun menjadi kebiasaan dan tertanam kuat dalam masyarakat Tolotang. Pemaksaan yang kemudian menjadi sebuah kebiasaan yang berasal dari struktur-struktur yang ada pada masyarakat Tolotang inilah yang kemudian menciptakan sebuah realita yang menjadi fakta sosial bahwa meskipun dunia mengalami perkembangan hidup yang cukup modern, namun masyarakat Tolotang masih hidup dalam nilai-nilai dan tradisinya yang kuat, dan mampu mempertahankan tradisi hingga saat ini, Hal tersebut disebabkan karena adanya strukturstruktur sosial pada masyarakat Tolotang yg mempunyai kekuatan yang memaksa dan mengendalikan.

(2) adanya keinginan mempertahankan tradisi, dibuktikan bahwa generasi sekarang menginginkan adanya pewarisan kebudayaan dalam hal tradisi pernikahan, ketika berbicara tentang pewarisan budaya atau tradisi berarti berbicara tentang kaum pemuda sebagai generasi penerus. Para pemuda dalam komunitas adat Towani Tolotang telah menampakkan antusias dan rasa keingintahuan mereka tentang tradisi pernikahan dengan menjadikan tradisi pernikahan yang dilakukan pemangku adat sebagai cerminan tradisi pernikahan yang mereka akan lakukan sehingga proses pernikahan yang dilakukan sekarang akan dilanjutkan ke generasi selanjutnya. Selain itu, berdasarkan hasil wawancara dan observasi peneliti juga mendapatkan bahwa di dalam tradisi pernikahan terdapat nilai-nilai sosial yang penting dalam memperkuat persatuan dan kesatuan di dalam masyarakat, menumbuhkan rasa ikhlas serta adanya rasa kepedulian tinggi. Nilai-nilai sosial tersebutlah yang mendorong untuk tetap melestarikan tradisi pernikahan tersebut.

Dari hasil penelitian terungkap pula bahwa dalam pernikahan Towani Tolotang tidak terdapat hal-hal yang melanggar yang dilakukan masyarakat, inilah merupakan bukti bahwa

masyarakat memiliki keinginan dalam mempertahankan tradisi yang telah dilakukan turun temurun namun, terdapat keringanan apabila terdapat sesuatu yang sifatnya emergency, atau mendesak maka dapat dilakukan dua atau tiga prosesi dalam sehari tanpa menghilangkan prosesi yang lain. hal 
tersebut sesuai dengan teori AGIL khususnya dalam hal adaptasi yang diungkapkan oleh Talcott Parson (Ritzer, 2012) mengungkapkan tentang adaptasi, suatu sistem harus mengatasi kebutuhan mendesak yang bersifat situasional eksternal. Sistem itu harus beradaptasi dengan lingkungannya dan mengadaptasikan lingkungan dengan kebutuhan-kebutuhannya. Jadi dalam pernikahan Towani Tolotang dapat bertahan hingga sekarang walaupun diterpa oleh arus modernisasi karena adanya adaptasi berupa pelaksanaan yang dulunya satu hari pelaksanaan untuk satu proses pernikahan, namun dalam hal emergency proses pernikahan dapat dilakukan sekaligus dua atau tiga, sehingga seluruh proses pernikahan dapat dilaksanakan walaupun dalam waktu yang lebih singkat dari biasanya.

3. Nilai-Nilai Sosial Dalam Pernikahan Towani Tolotang Di Kelurahan Amparita Kecamatan Tellu Limpoe Kabupaten

\section{Sidenreng Rappang}

Berdasarkan hasil penelitian yang dilakukan, peneliti mendapatkan 5 nilai-nilai sosial yang terdapat dalam pernikahan Towani Tolotang yakni (1) nilai gotong royong, gotong royong merupakan hal yang masih dipertahankan oleh masyarakat Towani Tolotang karena mereka memahami bahwa nilai gotong royong ini memberikan kebersamaan dan sifat sukarela dalam membantu antar sesama, nilai gotong royong sendiri sangat jelas nampak pada saat mendirikan sarapo yang biasanya dibantu puluhan sampai ratusan orang. (2) nilai tolong menolong, tolong menolong adalah adalah saling membantu antar sesama manusia tanpa mengharapkan imbalan apapun. Tolong menolong lebih kepada personal diri seseorang, apa yang bisa dilakukan untuk meringankan beban orang lain. hal tersebut terlihat pada saat mappenre botting dan mapparola, tetangga atau pun kerabat yang memiliki mobil akan dengan sukarela meminjamkan mobilnya. Selain itu tetangga ataupun kerabat akan membantu dalam hal memasak serta dokumentasi. (3) nilai kekeluargaan, Nilai kekeluargaan adalah suatu sikap untuk mempersatukan anggota keluarga dalam suatu budaya dan tatanan adat istiadat. Dengan adanya penyelenggaraan pernikahan dapat dijadikan sebagai alat bertemunya para keluarga dan sebagai tempat untuk mempererat tali persaudaraan sebab keluarga jauh maupun dekat akan berkumpul untuk menghadiri acara pernikahan tersebut. (4) nilai kepedulian, nilai kepedulian adalah sebuah perasaan tanggung jawab atas kesulitan yang dihadapi oleh orang lain dimana seseorang terdorong untuk melakukan sesuatu untuk mengatasinya Kepedulian yang dimaksud adalah timbulnya senasib sepenanggungan terhadap keluarga yang melaksanakan pernikahan. Hal tersebut terlihat pada saat kerabat maupun tetangga menanggung beberapa keperluan dalam pernikahan serta pemberian benda berharga saat mappaleppang.

(5) nilai pengormatan, Nilai penghormatan dalam pelaksanaan pernikahan perlu adanya, karena segala sesuatu yang dimulai dengan baik hasilnya akan baik. nilai penghormatan sendiri merupakan suatu sikap penghargaan dan

kekaguman kepada orang lain. nilai penghormatan dalam tradisi pernikahan Towani Tolotang yakni keseriusan seorang laki-laki melamar seorang perempuan adalah bentuk penghargaan serta penghormatan untuk si gadis dan keluarganya.

Berdasarkan kelima nilai sosial tersebut terdapat integrasi dalam teori AGIL oleh Talcott Person, (Ritzer, 2012) yang menyatakan "suatu sistem harus mengatur antar hubungan bagianbagian dari komponennya. Ia juga harus mengelola hubungan di antara tiga imperatif fungsional lainnya $(\mathrm{A}, \mathrm{G}, \mathrm{L})$. dalam proses

pernikahan Towani Tolotang sendiri dilaksanakan secara kekeluargaan, kegotong royongan, tolong menolong, kepedulian serta penghormatan yang dilakukan oleh masyarakat secara keseluruhan, inilah yang menandakan kuatnya integrasi para anggota masyarakat, sehingga dapat membuat persatuan dan kesatuan dalam masyarakat Towani Tolotang menjadi kuat dan dapat memelihara bagian-bagian pada sistem pernikahan Towani Tolotang tersebut.

\section{SIMPULAN DAN SARAN}

Berdasarkan penelitian yang telah dilakukan mengenai pernikahan di Kelurahan Amparita Kecamatan Tellu Limpoe Kabupaten Sidenreng Rappang, maka diperoleh beberapa kesimpulan yaitu:

(1) Proses Pernikahan Towani Tolotang Di Kelurahan Amparita Kecamatan Tellu Limpoe Kabupaten Sidenreng Rappang ada 3 proses atau tahapan, diawali dari (1) tahapan sebelum pernikahan (pra nikah) yaitu (a) Mabbaja Laleng, (c) Mappetu Ada, (d) Mappaenre Paddopo Addeng (e) Massarapo (f) Tangke (g) Mappenre Dui/ Pattere Pese (h) Diyo Majeng (i) Mapacci, (j) Lolang. (2) tahapan nikah/resepsi yaitu 
(a) mappenre botting (b) Tudang Botting (c) Mapparola (3) tahapan setelah pernikahan (pasca nikah) yaitu (a) Mabbeni Siwenni,

(b) Maccera Kawing, (c) Mappaleppang

(d) Mabbolo; (2) Konsistensi pernikahan towani tolotang di tengah arus modernisasi kehidupan yaitu (1) adanya keyakinan yang kuat yang bersumber dari nenek moyang, mereka percaya bahwa apa yang telah diwariskan oleh nenek moyang mereka adalah hal-hal yang akan membuat kehidupan mereka lebih terarah dengan adanya kepercayaan terhadap dewata sewwae. Ada 2 peran yang dilakukan dalam membentuk keyakinan yakni (a) peran orang tua, (b) peran uwa/uwatta (pemangku adat.

(2) adanya keinginan mempertahankan tradisi, yakni keingintahuan dari generasi muda komunitas towani tolotang tentang pernikahan adat tersebut sehingga nantinya akan timbul upaya melestarikan tradisi pernikahan tersebut. Selain itu, terdapat nilai sosial yang terdapat dalam pernikahan yang dapat memperkuat dan memperkokoh persatuan dan kesatuan dalam masyarakat;

(3) Nilai-nilai sosial dalam pernikahan towani tolotang di kelurahan amparita kecamatan tellu limpoe kabupaten sidenreng rappang yaitu (1) nilai gotong royong, (2)

nilai tolong menolong, (3) nilai kekeluargaan, (4) nilai kepedulian, (5) nilai pengormatan

Berdasarkan kesimpulan diatas, penulis memiliki beberapa saran yang terkait dengan pernikahan di Kelurahan Amparita Kecamatan Tellu Limpoe Kabupaten Sidenreng Rappang, yaitu: (1) Tradisi pernikahan Komunitas adat Towani Tolotang itu dapat dikatakan unik dalam prosesinya oleh karena itu perlu dijaga dan dipertahankan dengan baik sebab, tradisi pernikahan adat yang ada di Indonesia mulai mengalami perubahan seiring hadirnya modernisasi, pernikahan adat Komunitas adat Towani Tolotang sendiri merupakan salah satu kearifan lokal yang dapat menjadi potensi pariwisata budaya di Sulawesi Selatan khususnya Kabupaten Sidenreng Rappang; (2) Bertahannya suatu tradisi di dalam masyarakat tentu karena adanya kontribusi dari setiap lapisan masyarakat. Tidak terkecuali dalam Komunitas adat Towani Tolotang yang dalam melestarikan tradisinya dibutuhkan peran atau kontribusi dalam masyarakatnya, adapun kontribusinya yakni karena adanya peran orang tua, peran pemimpin adat atau Uwa serta keinginan dalam hal mempertahankan tradisi yang terlihat dari rasa keingintahuan dari generasi muda dari Komunitas adat Towani Tolotang, namun demikian peran serta kontribusi tersebut perlu ditingkatkan seiring dengan pesatnya arus modernisasi dan juga peranperan yang ada dalam

masyarakat perlu menunjukkan kontribusinya misalnya peran pemerintah setempat sehingga tradisi pernikahan khusunya bagi Komunitas adat Towani Tolotang ini dapat lebih berkembang tanpa menghilangkan budaya aslinya; (3) Setiap tradisi memiliki nilai sosial didalamnya, hal tersebut juga terdapat dalam pernikahan Tolotang, nilai sosial tersebut dapat mempererat kesatuan dan persatuan dalam masyarakat sehingga hal tersebut perlu untuk dipertahankan serta ditingkatkan sehingga nilai sosial tersebut dapat terealisasikan pula dalam kehidupan seharihari masyarakat Tolotan

\section{DAFTAR PUSTAKA}

Agustang. A. (2011a). Filosofi Research (Dalam Upaya Pengembangan Ilmu). Sarwah Press.

Agustang. A. (2011b). Pendekatan Penelitian Kualitatif dan Kuantitatif Suatu Tinjauan Kritis. Andira Publisher.

Agustang. A. (2015). Dasar-Dasar Filsafat Penelitian Untuk Pengembangan Ilmu. CV Multi Global.

Agustang, A. (2010). SUFISME DAN KEMISKINAN KULTURAL PADA KOMUNITAS NELAYAN DI PESISIR TELUK BONE KECAMATAN SIBULUE. AL-FIKR, $14, \quad 342-364$. http://journal.uinalauddin.ac.id/index.php/alfikr/article/view 
Phinisi Integration Review. Vol 3(2) Agustus 2020

$/ 2327$

Bahri, S. dkk. (2012). Kepercayaan dan Upacara Tradisional Komunitas Adat Di Sulawesi Selatan: Kajian Komunitas Adat Toani Tolotang dan Komunitas Kajang. De La Macca (Anggota Ikapi Sulawesi Selatan).

Damsar. (2015). Pengantar teori sosiologi. Prenada Media Group.

Ritzer, G. (2010). Teori Sosiologi Modern. kencana.

Ritzer, G. (2012). Teori Sosiologi (Dari Sosiologi Klasik Sampai Perkembangan Terakhir Postmodern). Pustaka Pelajar. 